Historic, Archive Document

Do not assume content reflects current scientific knowledge, policies, or practices. 



\section{Special Offer of Japanese Iris}

Price $\$ 1.00$ Per Doz., $\$ 7.50$ Per 100, F. O.B. Pittsburgh

Gelchillyo

After the Federal Government proclaimed Quarantine 37 , Awhish prohibited the importation of nursery stock, it wasnotongerpossible to import the fine named Japanese Iris. Believeing the loss of these Iris to American gardens would be irreparable, we decided to build up our own collections and for this purpose we imported great quantities. of seed from which to grow plants. When these plants bloomed the finest of them were set aside as the foundation for our future collections.

As is to be expected in growing the seed of any hybrid, less than five per cent of the plants grown from this seed were distinctive enough for our named collections. Seventy-five per cent produced flowers quite commonplace and these plants were discarded: The balance, some twenty per cent, produced flowers which were not individual enough for our named collections but which were, nevertheless, so fine that it seemed like a criminal waste to destroy them. It. occurs to us that you might like to have them and so while they last, we will furnish them at $\$ 1.00$ a dozen, $\$ 7.50$ per 100 .

We guarantee that all these Iris are selected plants grown from seed imported from the finest Iris collections of Japan. 



\section{EVERBLOOMING ROSES AT BARGAIN PRICES}

FROM NOW UNTIL NOVEMBER 1st

HYBRID TEA ROSES RECOMMENDED BY THE AMERICAN ROSE SOCIETY

PRICES EXCEPT WHERE NOTED, 65c EACH, $\$ 7.20$ DOZ., F.O. B. PITTSBURGH

That your rose orders may be handled as they arrive, we have built the finest nursery packing house in America and assembled a large group of trained plantsmen. These facilities and this organization have a potential capacity of over a thousand orders a day and if they could be used to capacity, we could clean up our rose business in three weeks and devote our energies to something else, thereby making possible a tremendous saving in handling costs. As it is, the rose business strings along throughout the season, resulting in much waste and lost motion.

To those of our customers who will co-operate with us in cutting out this waste we will give the benefit of resulting economies by reducing rose prices $35 \%$. Decide what roses you will want next Spring and send us your order now. When the proper planting time arrives, your order will be filled and the roses will cost you $65 \mathrm{c}$ each $\$ 7.20$ a dozen.

\section{"It's Too Much Trouble to Order Now"}

Very well, we will wait your convenience but you will have to pay for it. Next Spring these roses will cost you $\$ 1.00$ each, $\$ 10.00$ a dozen.

In any case whether you order your roses now at $65 \mathrm{c}$ or. next Spring at $\$ 1.00$, you will get exactly the same strictly No. 1 , two year old dormant plants: The finest roses obtainable.

\section{ELLIOTT NURSERY COMPANY}

Briarelinî. Exquisite blooms of hrllliant pink. Columbin. Heavy, douhle, hright light pink-blooms, deopening in the sunlight.

Danue Edith Helon. New. Brillant rose-pink.
Extremely double hlooms: $75 \mathrm{c}$ each, $\$ 8.00$ per doz

Dorothy Page-Roberts. Flowers copper-pink. $\$ 1.00$ each, $\$ 11.00$ per doz.

buchess of Wellington. Copper-yellow huds and uehess of
flowers.

Prank Reader. New. Light yellow flowers with darker center. $75 \mathrm{c}$ each, $\$ 8.00$ per doz.

(iriss an Teplitz. Flowers large velvety crimson.

Hadley. Dark red hlooms.

Irish Hope. New. Buds hrownish red. Flowers large crimson. $75 \mathrm{c}$ each, $\$ 8.00$ per doz.

Jonkheer J. L. Mock. Buds dark pink. Flowers hrilliant pink inside, crimson outside.

J. Otto Thilow. New. Bright shell-pink flowers

Kaiserin Augnste Viktoria. The flnest white ever hlooming rose.

KHlarney. Brilliant pink flowers.

Killarney Whlte. Pure suow-white.

Lady Allee Stanley. Dark pink flowers.

Lady Margaret Stewart. New. Buds golden-yellow y Margaret Stewart. New. Buds golden-yellow
stained copper and red. Flowers pure yellow. stained copper and red.
$\$ 1.00$ each, $\$ 11.00$ per doz.

Lord Charlemont. New. Brilliant crimson. $\$ 1.00$ each, $\$ 11.00 \mathrm{per}^{\circ} \mathrm{doz}$

Lns Angeles. Pale flesh-pink, stained rose and

Deliveries depending on weather conditions: To slates. last week of March; Northern States, April.

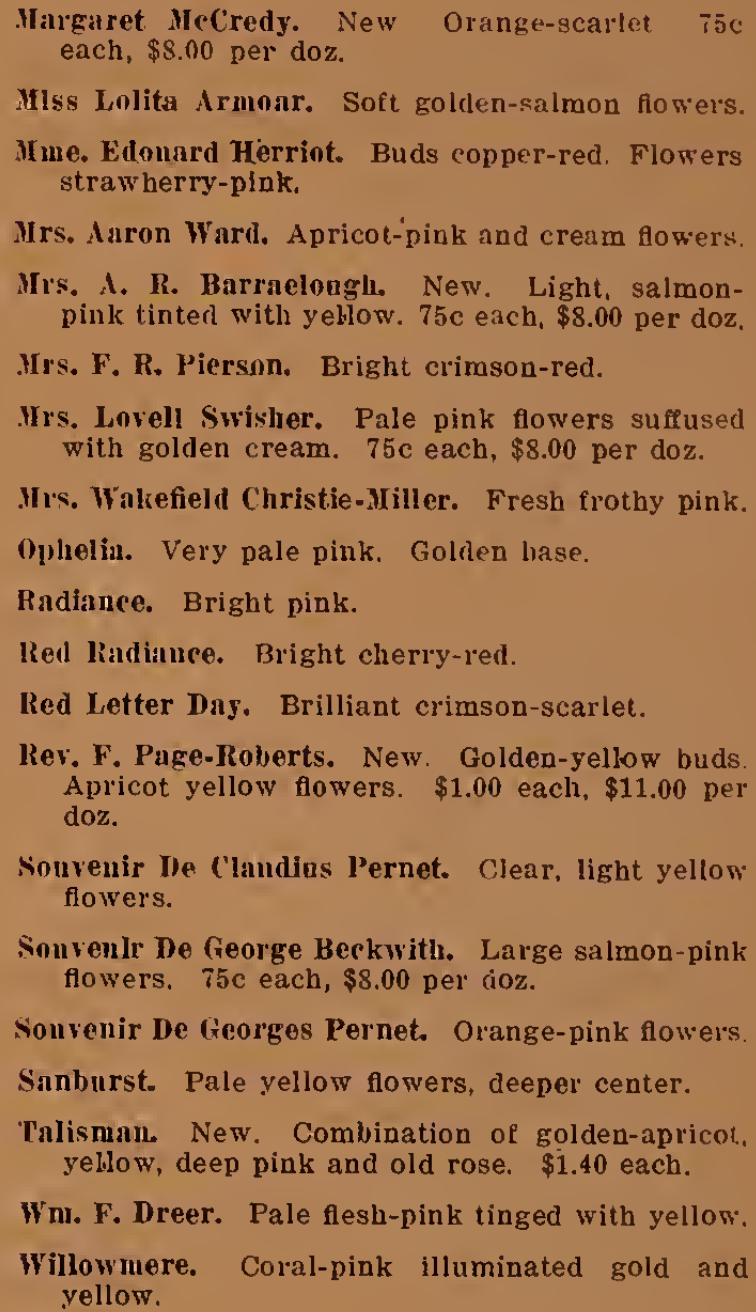

Sonvenir Ie Clandins Pernet. Clear, light yellow

nonvenIr De George Beckwith. Large salmon-pink flowers. $75 \mathrm{c}$ each, $\$ 8.00$ per cioz.

Souvenir De Georges Pernet. Orange-pink flowers.

Sanburst. Pale yellow flowers, deeper center.

Talisnan. New. Combination of golden-apricot, yellow, deep pink and old rose. \$1.40 each.

Wn. F. Dreer. Pale flesh-pink tinged with yellow: Willowmere. Coral-pink illuminated gold and
yellow.

\section{(1)}




\section{BARGAIN OFFER OF PEONIES}

Many years ago we checked over the list of available Peony varieties and decided that if certain of these varieties were available in quantities at a reasonable price, they would have a great future. Having confidence in our judgment we started in to grow them extensively and for ten years and more we have enjoyed, as the result of aur foresight, a large and profitable business in Peonies.

The time has come for another check-up on Peony varieties. We believe that there are half a dozen or so Peonies which are now scarce and high priced which will sooner or later supplant the present favorites in popular approval. We intend to be in a position to cash in on this market when it arrives.

In order to make room for increased plantings of the newer things it is necessary to reduce our plantings of these present favorites. While the stock lasts we will furnish the following named Peonies at bargain prices:

\section{FIVE STRIKING PEONIES}

Each Doz.

Each Doz.

Edulis Superba. Bright old-rose, slightly lighter towards the center.

One of the earliest to bloom.

$35 \mathrm{c} \quad \$ 3.50$

Edulis Alba. Medium size, bomb type flower. White with a cream white center flecked with crimson

$30 \mathrm{c} \cdot 3.00$

Mrs. George Bunyard. 'A very large double flower; bright rose, sweetly $35 \mathrm{c} \quad 3.50$

Prince Prosper D'Arensberg. A lateflowering Peony with extra large lark wine-red blooms …................... $30 \mathrm{c}$

Rosea Elegans. Pale Lilac rose; guards clear. Colliar cream white; central petals tipped with crimson $35 \mathrm{c} 3.50$

1 each above varieties ( 5 plants) $\ldots \ldots \ldots \ldots \ldots \ldots \ldots \ldots$
3 each above varieties (15 plants) $\ldots \ldots \ldots \ldots \ldots \ldots \ldots \ldots \ldots \ldots \ldots$
(f each above varieties (30 plants) $\ldots \ldots \ldots \ldots \ldots \ldots \ldots \ldots \ldots \ldots \ldots \ldots \ldots$

We guarantee that these Peonies are identical in size, condition, etc., with the same varieties listed on pages 21 and 22 of this catalog at regular prices.

\section{BEARDED IRIS TOO}

Some new Bearded Iris will dominate the market five or six years hence, and we intend to be ready for this also. To make room some of the present favorites must be sacrificed. The following varieties are offered at bargain prices:

\section{SIX DISTINCT TALL BEARDED IRIS}

Doz. Per 100

Aurea. Soft Yellow throughout, faintly reined; brownish orange beard. 'The most popular Iris

$\$ 1.25 \$ 9.00$

florentina purpurea. Standards, blue; falls velvety purple, bright yellow beard

$1.10 \quad 8.00$

Florentina alba. Standards and falls creamy. white, faintly flushed with lavender; fragrant

$1.15 \quad 8.50$
Kochii. Claret purple

Doz. Per 100

1.5011 .00

Lohengrin. Standards and falls light rosy purple, giving the bloom a pale silvery pink effect

$1.20 \quad 9.0$

Princess Victoria Louise. Standards lemon-yellow; falls reddish purple, bordered cream

3 each above varieties (18 plants)

12 each above varieties ( 72 plants)

$\$ 7.00$

We guarantee that these Bearded Iris are identical in size, condition, etc., with the same varieties listed on page 18 of this catalog at regular prices.

\section{ELLIOTT NURSERY COMPANY 505 MAGEE BLDG. PITTSBURGH, PENNA.}

